Journal of Engineering and Applied Sciences 14 (Special Issue 7): 10195-10201, 2019

ISSN: 1816-949X

(C) Medwell Journals, 2019

\title{
Simulation of Solar Collector Performance under Different Operating Conditions
}

\author{
Abbas Sahi Shareef and Shahad Sattar Moneem \\ Department of Mechanical Engineering, Kerbela University, Kerbela, Iraq
}

\begin{abstract}
The research involved verifying the effect of solar radiation on the heat transfer process of a solar radiation simulator through a regulator designed to change the radiation intensity of a halogen type (9) that was used as simulation instead of sunlight with three rates $\left(500,800,1100 \mathrm{~W} / \mathrm{m}^{2}\right)$. Three flow rates $(1,1.5,2 \mathrm{~L} / \mathrm{min})$ were also used within the flux. The experiments were conducted in Karbala, Iraq with a latitude 32.60 North. Five angles of the solar complex were used for each test inside a closed room. The results showed that the maximum temperature difference between the input and exit of water during the solar complex is $10.8^{\circ} \mathrm{C}$ obtained at a flow rate $1 \mathrm{~L} / \mathrm{min}$, radiation rate $1100 \mathrm{~W} / \mathrm{m}^{2}$ and angle $22^{\circ}$ the numerical simulation program ANSYS was also used to solve the numerical side and the numerical results of the exit temperature of the solar collector system showed reasonable agreement with the practical results. Where it was found that the maximum percentage of error between the results of the process and the numerical was $5 \%$.
\end{abstract}

Key words: Solar collector flat panel type, halogen lights, temperature difference between entry and exit, flow rate, radiation rate, collector

\section{INTRODUCTION}

Sun is the main source of energy in the solar system. It offers us the energy of great potential in terms of supplying the world's need. As the primary energy resources are depleting continuously, solar energy draws the attention of researchers throughout the world. Solar energy is one of the alternative energies that have vast potential. It is estimated that the earth receives approximately $1000 \mathrm{~W} / \mathrm{m}^{2}$ amount of solar irradiation in a day (Winston et al., 2005).

The solar radiation incident on the Earth's surface is comprised of two types of radiation-beam and diffuse (Rapp, 1981). A solar collector is a device which transfers the collected solar energy to a fluid passing in contact with it so, it is always a matter of investigation to know that how efficiently solar collectors are converting solar energy into thermal energy (Garg and Prakash, 1997). Flat-plate collectors are the most widely used kind of collectors in the world for domestic solar water heating and solar space heating applications. The development of the flat plate collector used for this study harden (form, fix or join by soldering with an alloy of copper and zinc at high temperature) riser and header pipes, plate material, cover of glass (Ion and Maratins, 2006) and wood box, it consist of two header and six vertical tube riser risers. The risers connected to the headers by drilling and harden the absorber plate from stainless steel attached with riser tubes (Ekramian et al., 2014; Billy et al., 2014), the absorber was coated with black car paint type (Matt 890) with $50 \%$ by weight river sand has a great absorbing surface for plate to maximize the absorbance of the radiant energy (Khudhair and Shahad, 2012; Govaer,
1988) investigation, experimental to display that solar collectors can be tested by utilizing simulators aglow lamps of radiation is properly estimated. This can be accomplished by equating the solar radiation to simulate radiation when they both lead to an equal rise in the plate temperature above ambient at stagnation under constant conditions. Shatat et al. (2013) the novel solar simulator was designed and built to simulate solar irradiance, its consists array of (30) halogen lamps each one had power $(400 \mathrm{~W})$, a uniform geometrical arrangement design was estimated for a solar simulator by its luminance distribution in order to optimize the maximum source to target transfer efficiency of irradiative power. Experimental tests were performed for different distances from the simulator surface. It observed that the optimal distance between the solar collector and the light surface simulator was about $23 \mathrm{~cm}$ at several solar irradiance. Sultan et al. (2012) investigation optimal tilt angles for solar collectors in three Iraqi cities (Kirkuk, Baghdad and Nasiriya). The amount of radiation flux on a solar collector is mainly affected by the installation angle the monthly average daily global solar radiation on horizontal surfaces for (Kirkuk, Baghdad and Nasiriya) was measured. The solar collector can be oriented at three various cases, the first case, setting the collector at each month of the year in order to give maximum solar irradiation (realize optimum tilt angle of the collector). The second case proposes the seasonal changes (from Winter, Spring, Summer to Autumn) by utilizing the average value of each 3 months in order to give one season. The final case for collectors can be achieved by utilizing the average of the four seasons to obtain on a yearly average throughout the year. 
Finally, we obtain experimentally the range between Summer and Winter is \pm 20 from latitude (Mohamed et al., 2015) the performance of the Solar Water Heating system (SWH) depends on the absorber in the solar collector. Where it found that in countries that have unsuitable weather conditions, the indoor testing of solar collectors is preferred with utilizing a solar simulator halogen lamps for an heat source. It is operated with three variables of solar irradiation of 400,550 and $700 \mathrm{~W} / \mathrm{m}^{2}$ with utilizing three various sites of angles at 0,45 and $90^{\circ}$. Saleh et al. (2012) showed a simulation of the one-dimensional mathematical model for the transient processes occurring in liquid flat-plate solar collectors. Taking time-dependent thermos physical properties and heat transfer coefficients study and determining equations of the energy conservation for the glass cover, air gap between cover and absorber, absorber, working fluid, insulation and the storage tank, the differential equations by using the (implicit finite difference) method is executed using the MATLAB program. That validated the proposed method, experiment for several days with unsteady ambient conditions and flow rates. The efficiency of the proposed method was confirmed by experimental verification. The analysis confers a good agreement between the experimental and numerically predicted values for different operating conditions and flow rates that found after $50 \mathrm{~min}$ of operating the test temperatures difference about $3^{\circ} \mathrm{C}$ at the solar irradiance of $849.6 \mathrm{~W} / \mathrm{m}^{2}$ and flow rate $1.5 \mathrm{GPM}$ and a $3.5^{\circ} \mathrm{C}$ after an hour with a solar irradiance of $891 \mathrm{~W} / \mathrm{m}^{2}$ with the same flow rate.

\section{MATERIALS AND METHODS}

Experimental device and procedure: A schematic diagram of the experimental setup and the photographic of FPSC are shown in Fig. 1 and 2, respectively. The collector specifications are given in Table 1. When solar radiation of halogen lamps passes through a glass cover and hitting the blackened absorber surface of high absorptive, a large part solar energy is absorbed by the plate heat up, changing solar energy into heat energy. The heat is transferred to the transport medium in the fluid tubes to be carried away for storage or use. The fluid circulates in a closed system with using the water pump.

Experimental procedure: The solar collector performance has experimentally investigated in Karbala, Iraq latitude $32.6^{\circ} \mathrm{N}$ and longitude $44.02^{\circ} \mathrm{E}$ data is recorded under transient conditions. The solar collector is tilted to South facing with $12^{\circ} 22,32,42,52$ in Summer, the beam component is more than the diffuse component and thus the the main contribution comes from the beam component that leading to the optimum tilt is less usually latitude $-10^{\circ}$ (Gunerhan and Hepbasli, 2007) (Table 2).

Experimental set up consists from flat plate solar collector, simulation of solar radiation consist of 9 of halogen lamps each one give $500 \mathrm{~W}$, closed working fluid system and measurement devices solar power meter to record solar radiation from lamps. The electric pump circulates the working fluid through the solar collector. The tank capacity is nearly $8 \mathrm{~L}$. A flow meter is installed on the pipe after the electric pump. Simple manual valves and by pass pipes system was used to control on the flow rate of working fluid. The flow rate was measured by flow meter range $1-8 \mathrm{~L} / \mathrm{min}$, accuracy $\pm 5 \%$.

Twelve thermocouples type $\mathrm{K}$ was used to measure inlet and outlet fluid temperatures, cover glass, ambient, riser pipes, absorber plate temperatures and these thermocouples was connected through a temperature meter 12 channels temperature recorder, model: BTM-4208SD, SD card real time data recorder, accuracy

Table 1: The specifications of flat plate solar collector components

\begin{tabular}{|c|c|c|}
\hline Component & Dimensions & Remarks \\
\hline Absorber plate & $0.95 \times 0.526 \times 0.003 \mathrm{~m}$ & Material: stainless steel \\
\hline Glass cover & Thick $4 \mathrm{~mm}$ & window glass \\
\hline Collector area & $1.04 \times 0.64 \times 0.12 \mathrm{~m}$ & \\
\hline Header pipes & Inner diameter $16 \mathrm{~mm}$, outer diameter $20 \mathrm{~mm}$ Length $60 \mathrm{~cm}$ & Copper \\
\hline Riser pipe & $\begin{array}{l}\text { Inner diameter } 8 \mathrm{~mm} \text {, outer diameter } 10 \mathrm{~mm} \text { Length } 80 \mathrm{~cm} \text {, center to } \\
\text { center distance } 7.5 \mathrm{~cm}\end{array}$ & $\begin{array}{l}\text { Copper } \\
\text { No. of tubes: six }\end{array}$ \\
\hline edges insulation & Thick $3 \mathrm{~mm}$ & Glass wool \\
\hline Bottom insulation & Thick $45 \mathrm{~mm}$ & Glass wool \\
\hline Tilt angle & $12^{\circ}, 22^{\circ}, 32^{\circ}, 42^{\circ}, 52^{\circ}$ & Due to Summer months \\
\hline
\end{tabular}

Table 2: The specifications of solar collector

\begin{tabular}{ll}
\hline Components & Remarks \\
Collector & The dimension of collector is width $0.64 \mathrm{~m}$, length $1.04 \mathrm{~m}$ and thickness $0.12 \mathrm{~m}$ \\
Absorber plate & The dimension of collector is width $0.53 \mathrm{~m}$, length $0.95 \mathrm{~m}$ and thickness $0.03 \mathrm{~m}$ \\
& Material: black painted stainless steel \\
Transparent cover & $4 \mathrm{~mm}$ thick material: ordinary window glass \\
Raiser pipes & Inner diameter $8 \mathrm{~mm}$, outer diameter $10 \mathrm{~mm}$, tube center to center spacing distance $7.5 \mathrm{~cm}$, length $80 \mathrm{~cm}$, \\
& Material: copper No. of tubes: six \\
Header pipes & Inner diameter $16 \mathrm{~mm}$, outer diameter $20 \mathrm{~mm}$, length $60 \mathrm{~cm}$ \\
& Material: copper, No. of tubes \\
insulation & The insulation from all side, edge $0.03 \mathrm{~m}$ thick and bottom is $0.045 \mathrm{~m}$ thick \\
& Material: glass wool \\
Title angle & The tilted angle is $22^{\circ}$ take experimentally by comparison the solar irradiance with $12^{\circ}, 32^{\circ}, 42^{\circ}$ and $52^{\circ}$ \\
\hline
\end{tabular}




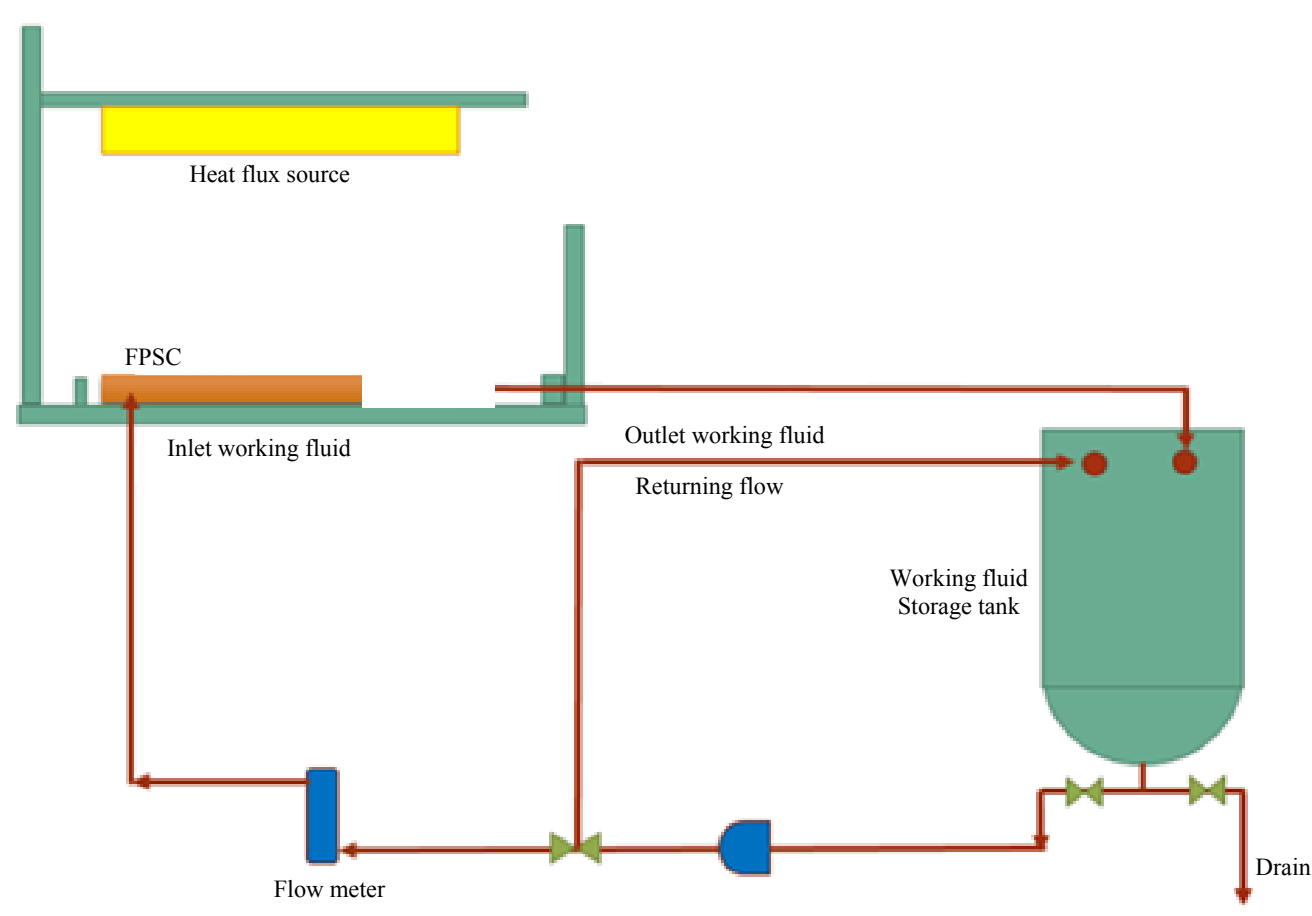

Fig. 1: The schematic of flat plate solar collector

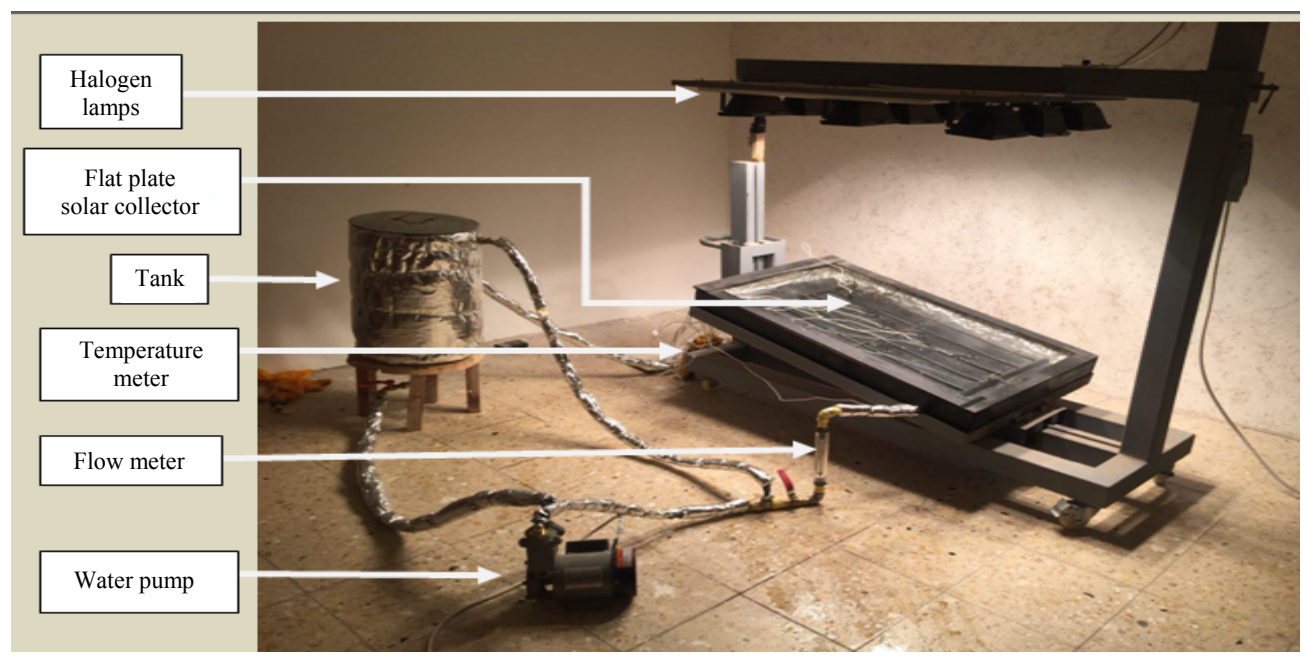

Fig. 2: A photographic of the experimental setup

$\pm(0.4 \%+1)$. The saving data will present into the Excel Software Fig. 3. Temperature meter and thermocouples the total solar radiation was measured by digital solar power meter (TES, Model-1333R, accuracy $\pm 5 \%$, Range-1-2000 W/ $/ \mathrm{m}^{2}$ ). The cosine loss of the beam component was removed because the collector is tilted from the horizontal. Thermocouples are connected to the solar collector by welding solder of end thermocouple with the surface to be estimating its temperature and covering with adhesive thermal insulator for insulating from environment and outside effects. Figure 3 and 4 illustrates network thermocouples distribution of the solar collector.

Also, the device design and build to simulate solar irradiance by using (Govaer, 1988) lamps (halogen) heat light, the frame design separately parts, all parts are 


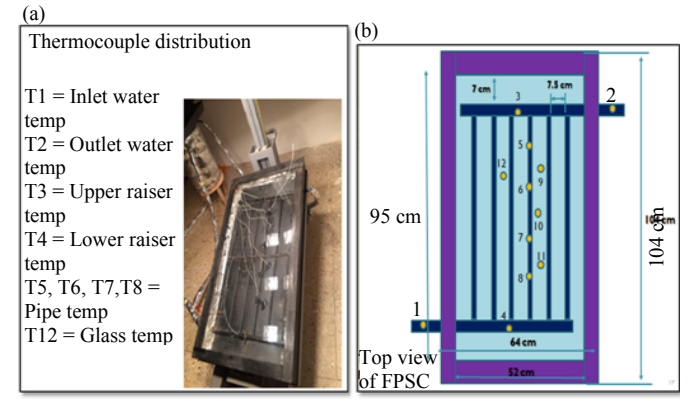

Fig. 3 a, b): Network thermocouples distribution of the solar collector

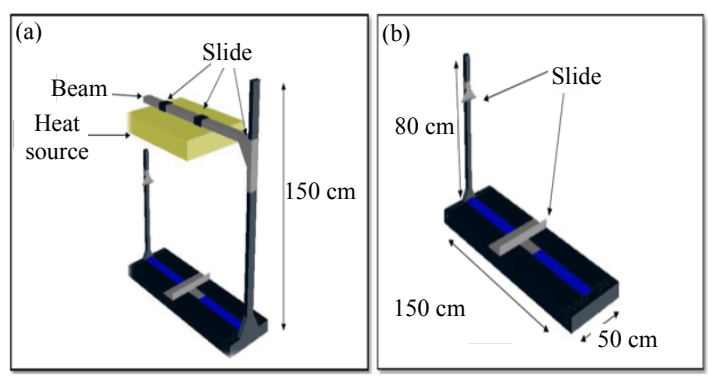

Fig. 4a, b): The autoCAD drawing explain the frame of the device

connected by the screw and connected the frame with a base, this base able to be change the solar collector tilt angle between $\left(0-90^{\circ}\right)$ as shown in Fig. 4 .

\section{RESULTS AND DISCUSSION}

The experiments were conducted for $2 \mathrm{~h}$ in Karbala, Iraq for flow rate of the working fluid 1, 1.5, $2 \mathrm{~L} / \mathrm{min}$ with the incident radiation of halogen lamps 500, 800 and 1100 $\mathrm{W} / \mathrm{m}^{2}$ with using the solar collector is tilted to south facing with angle $12^{\circ} 22,32,42,52$ were recorded the temperature every $5 \mathrm{~min}$. Figure 5-10 shows the outlet-inlet temperatures difference of water with time for flow rate $1 \mathrm{~L} / \mathrm{min}$ with the other conditions noticed that maximum different temperature between inlet and outlet $10.8^{\circ} \mathrm{C}$ was recorded at the condition angle $22^{\circ}$, IR $1100 \mathrm{~W} / \mathrm{m}^{2}$.

And by repeated the experiment on the other flow rate $1.5 \mathrm{~L} / \mathrm{min}$ with the other conditions shown in Fig. 11-15 noticed that maximum different temperature between inlet and outlet $7^{\circ} \mathrm{C}$ was recorded at the condition angle $22^{\circ}$, IR $1100 \mathrm{~W} / \mathrm{m}^{2}$.

And by repeated the experiment on the other flow rate $2 \mathrm{~L} / \mathrm{min}$ with the other conditions shown in Fig. 16-20 noticed that maximum different temperature between inlet and outlet $5.5^{\circ} \mathrm{C}$ was recorded at the condition angle $22^{\circ}$, IR $1100 \mathrm{~W} / \mathrm{m}^{2}$.

Turns out that the maximum temperature diffident was $10.8^{\circ} \mathrm{C}$ accurse in the condition angle $22^{\circ}$, incident

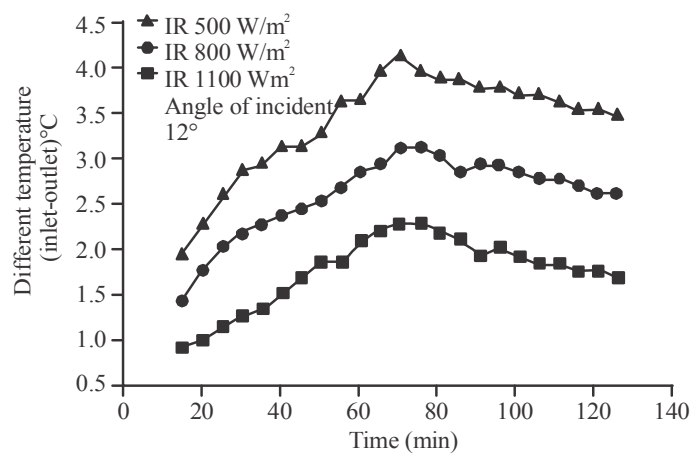

Fig. 5: The outlet-inlet temperatures difference of water with time for condition flow rate $1 \mathrm{~L} / \mathrm{min}$, angle of collector $12^{\circ}$ with the incident radiation 500 , $800,1100 \mathrm{~W} / \mathrm{m}^{2}$

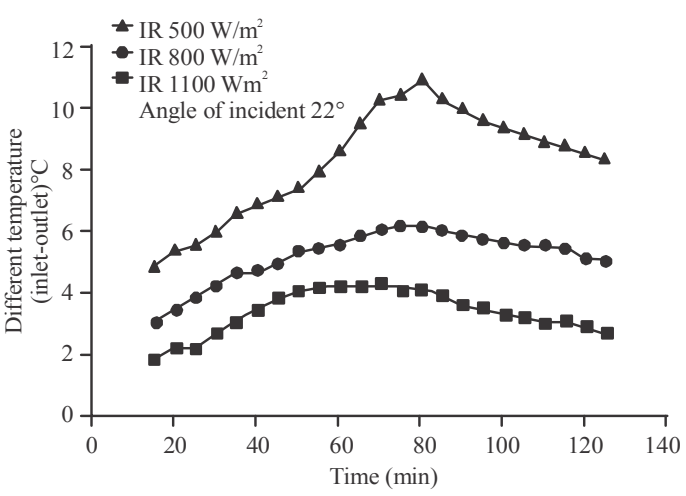

Fig. 6: The outlet-inlet temperatures difference of water with time for condition flow rate $1 \mathrm{~L} / \mathrm{min}$, angle of collector $22^{\circ}$ with the incident radiation 500 , $800,1100 \mathrm{~W} / \mathrm{m}^{2}$

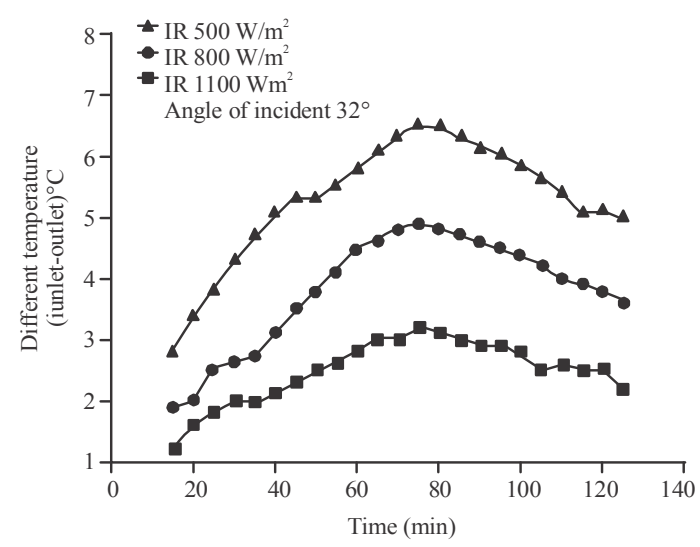

Fig. 7: The outlet-inlet temperatures difference of water with time for condition flow rate $1 \mathrm{~L} / \mathrm{min}$, angle of collector $32^{\circ}$ with the incident radiation 500,800 , $1100 \mathrm{~W} / \mathrm{m}^{2}$ 


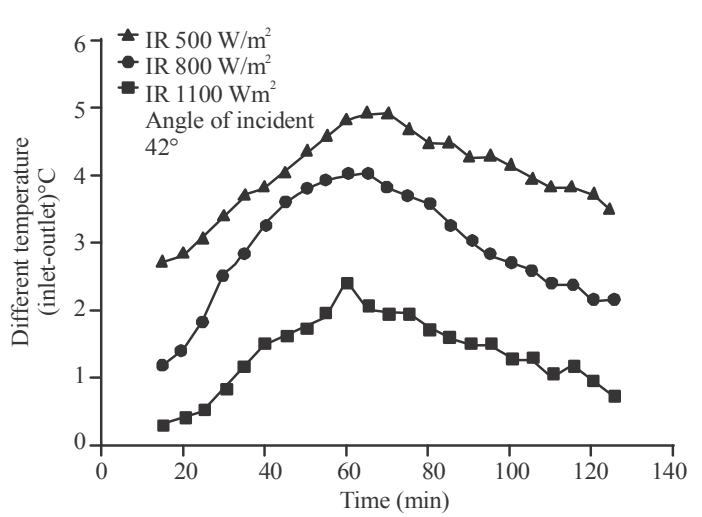

Fig. 8: The outlet-inlet temperatures difference of water with time for condition flow rate $1 \mathrm{~L} / \mathrm{min}$, angle of collector $42^{\circ}$ with the incident radiation 500,800 , $1100 \mathrm{~W} / \mathrm{m}^{2}$

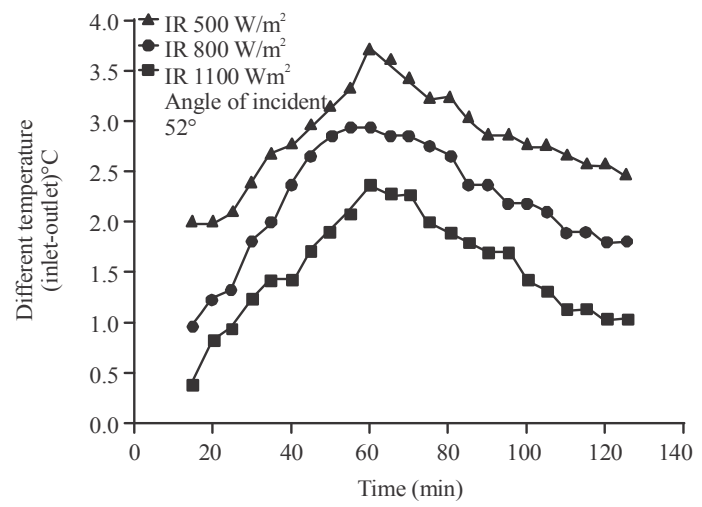

Fig. 9: The outlet-inlet temperatures difference of water with time for condition flow rate $1 \mathrm{~L} / \mathrm{min}$, angle of collector $52^{\circ}$ with the incident radiation 500 , $800,1100 \mathrm{w} / \mathrm{m}^{2}$

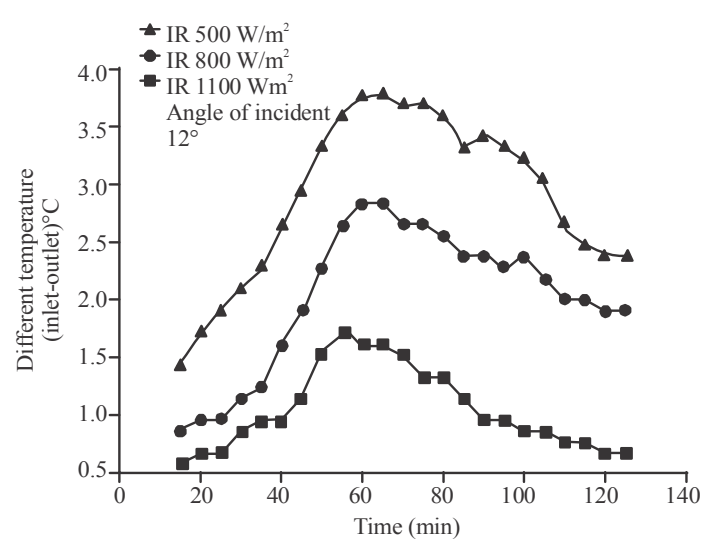

Fig. 10: The outlet-inlet temperatures difference of water with time for condition flow rate $1.5 \mathrm{1} / \mathrm{min}$, angle of collector $12^{\circ}$ with the incident radiation $500,800,1100 \mathrm{~W} / \mathrm{m}^{2}$

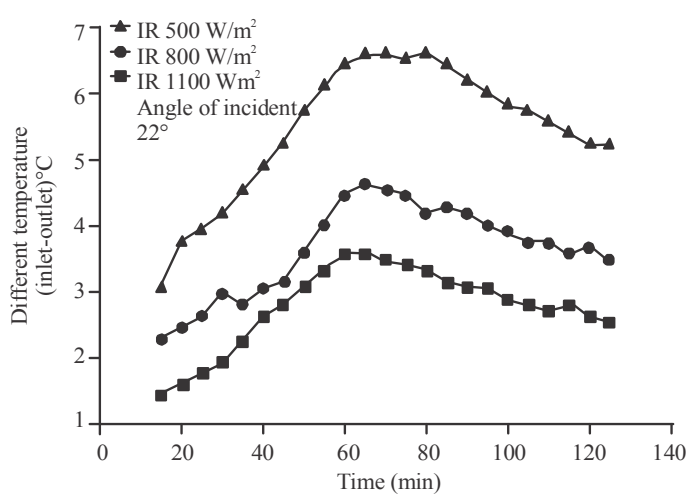

Fig. 11: The outlet-inlet temperatures difference of water with time for condition flow rate $1.5 \mathrm{l} / \mathrm{min}$, angle of collector $22^{\circ}$ with the incident radiation 500 , $800,1100 \mathrm{~W} / \mathrm{m}^{2}$

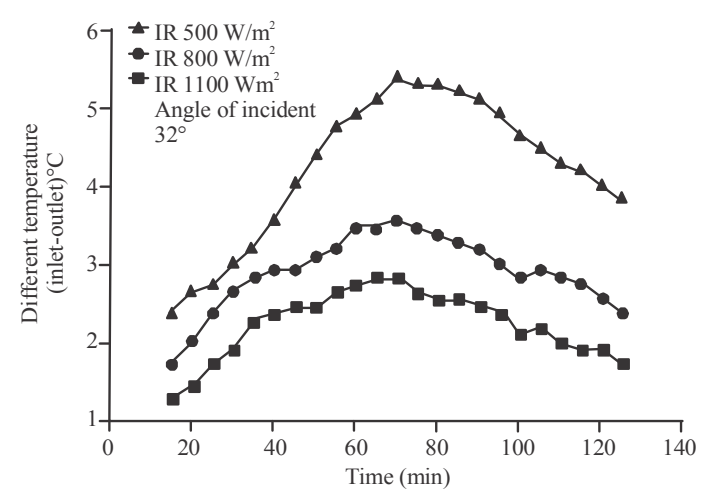

Fig. 12: The outlet-inlet temperatures difference of water with time for condition flow rate $1.5 \mathrm{~L} / \mathrm{min}$, angle of collector $32^{\circ}$ with the incident radiation $500,800,1100 \mathrm{~W} / \mathrm{m}^{2}$

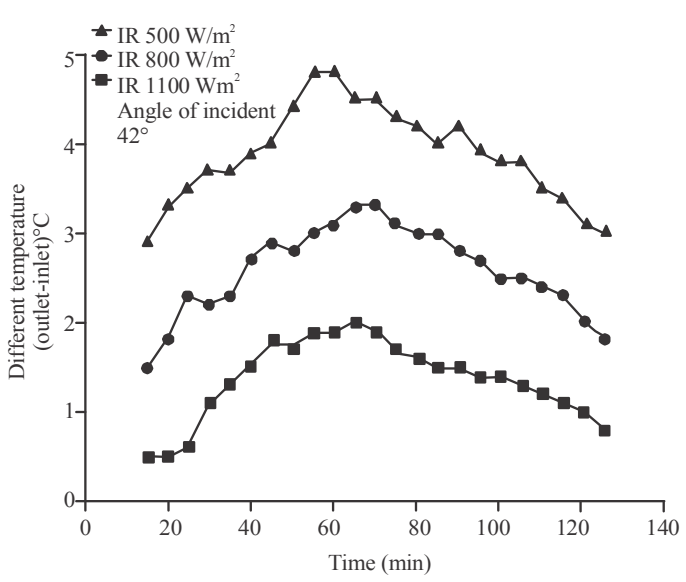

Fig. 13: The outlet-inlet temperatures difference of water with time for condition flow rate $1.5 \mathrm{~L} / \mathrm{min}$, angle of collector $42^{\circ}$ with the incident radiation $500,800,1100 \mathrm{~W} / \mathrm{m}^{2}$ 


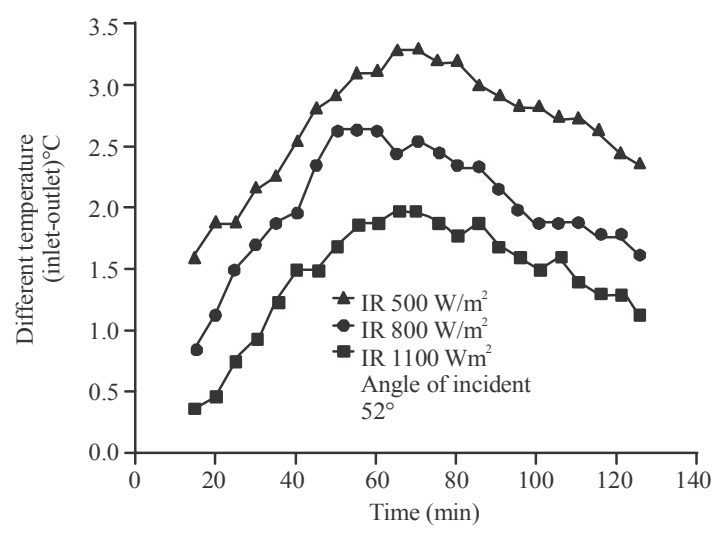

Fig. 14: The outlet-inlet temperatures difference of water with time for condition flow rate $1.5 \mathrm{~L} / \mathrm{min}$, angle of collector $52^{\circ}$ with the incident radiation $500,800,1100 \mathrm{~W} / \mathrm{m}^{2}$

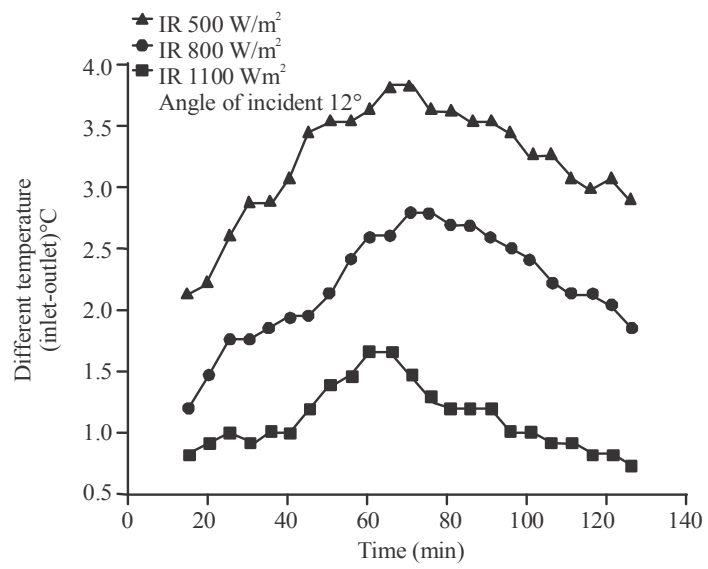

Fig. 15: The outlet-inlet temperatures difference of water with time for condition flow rate $2 \mathrm{~L} / \mathrm{min}$, angle of collector $12^{\circ}$ with the incident radiation 500 , 800 and $1100 \mathrm{~W} / \mathrm{m}^{2}$

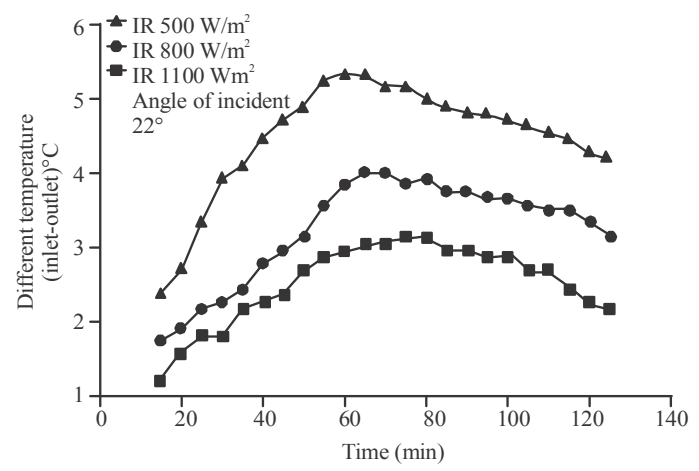

Fig. 16: The outlet-inlet temperatures difference of water with time for condition(flow rate $2 \mathrm{~L} / \mathrm{min}$, angle of collector $22^{\circ}$ with the incident radiation 500 , $800,1100 \mathrm{~W} / \mathrm{m}^{2}$

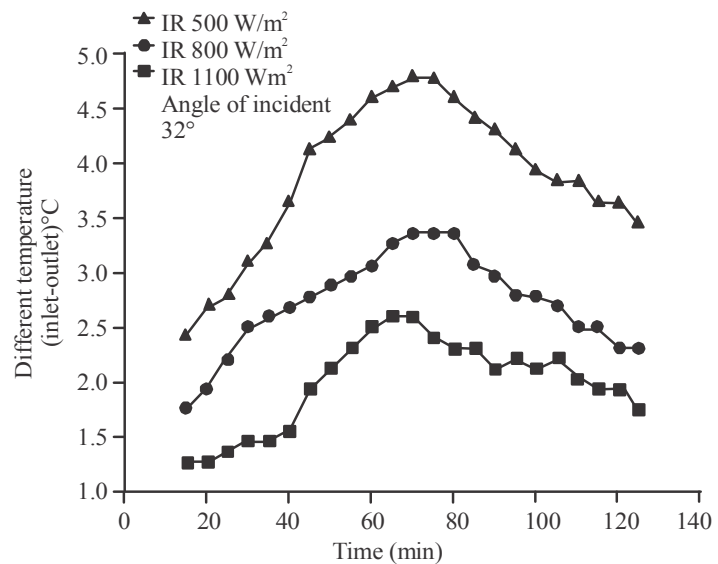

Fig. 17: The outlet-inlet temperatures difference of water with time for condition flow rate $2 \mathrm{~L} / \mathrm{min}$, angle of collector $32^{\circ}$ with the incident radiation 500 , $800,1100 \mathrm{~W} / \mathrm{m}^{2}$

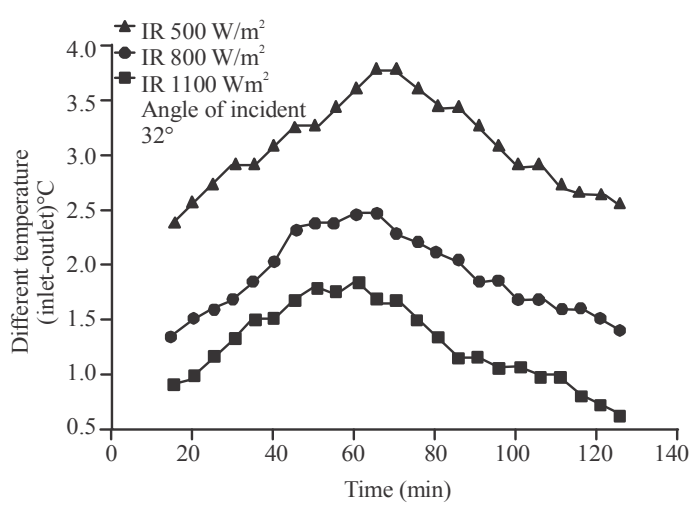

Fig. 18: The outlet-inlet temperatures difference of water with time for condition flow rate $2 \mathrm{~L} / \mathrm{min}$, angle of collector $42^{\circ}$ with the incident radiation $(500$, 800 and $1100 \mathrm{~W} / \mathrm{m}^{2}$ )

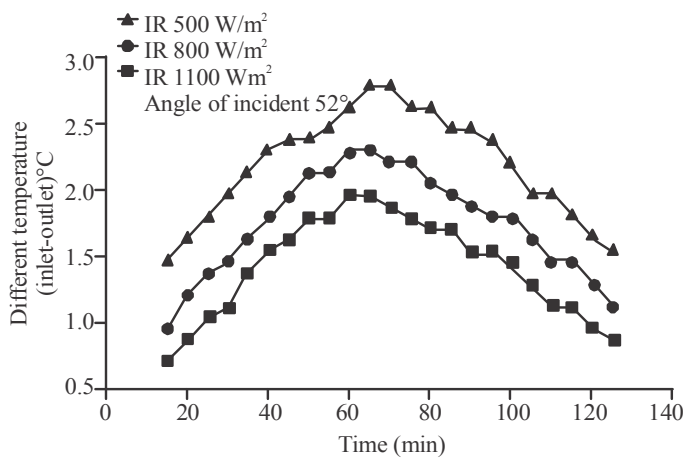

Fig. 19: The outlet-inlet temperatures difference of water with time for condition flow rate $2 \mathrm{~L} / \mathrm{min}$, angle of collector $52^{\circ}$ with the incident radiation 500 , $800,1100 \mathrm{~W} / \mathrm{m}^{2}$ 


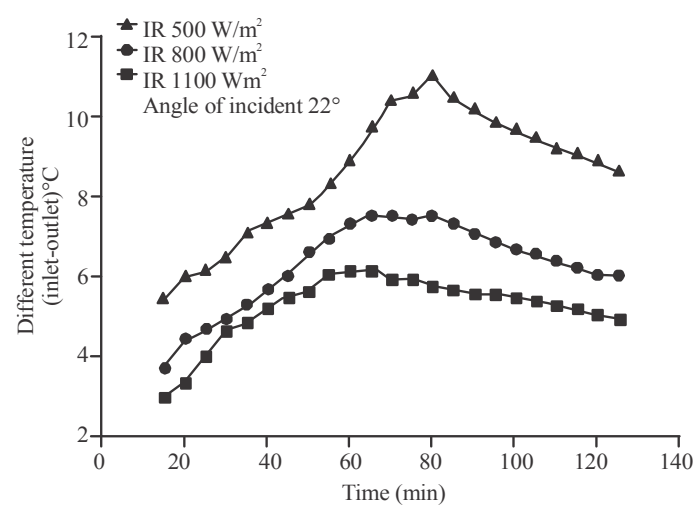

Fig. 20: The cooperation between the different flow rate $1,1.5,2 \mathrm{~L} / \mathrm{min}$ at angle of collector $22^{\circ}$ with the incident radiation $1100 \mathrm{~W} / \mathrm{m}^{2}$

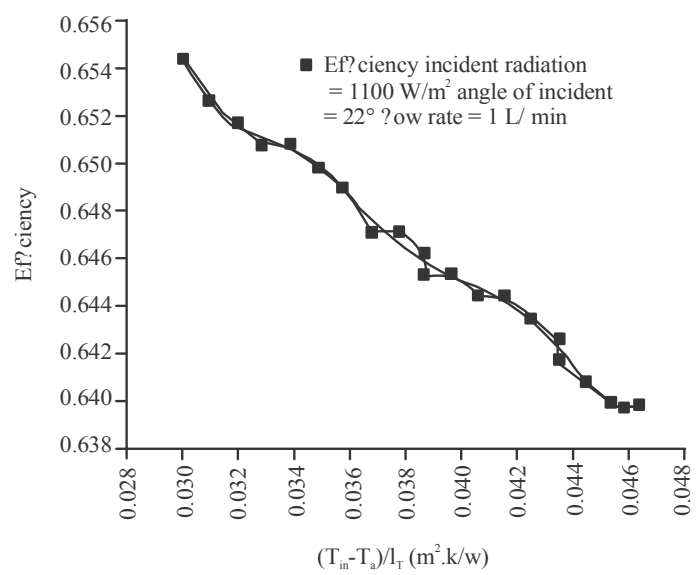

Fig. 21: Thermal efficiency

radiation $1100 \mathrm{~W} / \mathrm{m}^{2}$, flow rate $1 \mathrm{~L} / \mathrm{min}$, so, the cooperation between the different flow rate with the other conditions was shown in Fig. 21.

The thermal efficiency of the best condition was $65 \%$ and decreasing over time with the reduced parameters $\mathrm{T}_{\mathrm{i}}-\mathrm{T}_{\mathrm{a}} / \mathrm{I}_{\mathrm{T}}$ as shown in Fig. 21 at the above best condition

\section{CONCLUSION}

The solar simulator given the perfect compression between cases due to all parameter and boundary condition are controlled from the above results noticed that the maximum different temperature between inlet and outlet $10.8^{\circ} \mathrm{C}$ was recorded at the condition $1 \mathrm{~L} / \mathrm{min}$, angle $22^{\circ}$, IR $1100 \mathrm{~W} / \mathrm{m}^{2}$, so, it was noticed that lessening the flow rate which leads to increasing the temperature difference between outlet and outlet of the water at the low flow rate $1 \mathrm{~L} / \mathrm{min}$ the velocity of the flowing fluid is small, therefore, causes gain more solar energy during the time that means is allowing the rise of outlet temperature, the working fluids temperature difference was lessening with increasing the flow rate of working fluid, vice versa. While the low flow rate the working fluid is taken a long time inside the solar collector that means more absorber solar energy through the time. The minimum temperature difference at $2 \mathrm{~L} / \mathrm{min}$, the efficiency of the collector was decreased with theincreased the reduced parameter $T_{i}$ $\left.T_{\mathrm{a}}\right) / \mathrm{T}_{\mathrm{T}}$, the thermal efficiency increasing with increases the flow rates due to the difference between $T_{i}-T_{a}$ is less compared to the low flow rate and so that, the energy lost is less.

\section{REFERENCES}

Billy, A.S., T.Z.S. Ali, M.F. Zainudin and A.B. Rosli, 2014. Experimental study of water heating efficiency between Aluminium and Copper absorber plate in solar flat plate collector. Appl. Mech. Mater., 660: 709-713.

Ekramian, E., S.G. Etemad and M. Haghshenasfard, 2014. Numerical Analysis of Heat Transfer Performance of Flat Plate Solar Collectors. J. Fluid Flow Heat Mass Transfer, 1: 38-42.

Garg, H.P. and J. Prakash, 1997. Solar Energy: Fundamentals and Applications. Tata McGraw Hill, New Delhi, India, ISBN:9780074631416, Pages: 435.

Govaer, D., 1988. Indoor collector testing with an incandescent simulator. Sol. Energy, 40: 363-368.

Gunerhan, H. and A. Hepbasli, 2007. Determination of the optimum tilt angle of solar collectors for building a0pplications. Build. Environ., 42: 779-783.

Ion, I.V. and J.G. Maratins, 2006. Design, developing and testing of a solar air collector. Ann. Refrigeration Tech., 1: 1-4.

Khudhair, N.Y. and H.A.K. Shahad, 2012. Design, construction and testing of a solar air heater in Iraq. Acad. J. Sci., 1: 323-332.

Mohamed, N., A.F. Ismail and Z.A.A. Majid, 2015. Performance evaluation of solar collectors using a solar simulator. IIUM. Eng. J., 16: 79-90.

Rapp, D., 1981. Solar Energy. Prentice-Hall, Englewood Cliffs, New Jersey, USA., ISBN:9780138222130, Pages: 516.

Saleh, A.M., 2012. Modeling of flat-plate solar collector operation in transient states. MSc Thesis, Purdue University Fort Wayne, Fort Wayne, India.

Shatat, M., A. Mayere and S. Riffat, 2013. A standardized empirical method of testing solar simulator coupled with solar tube and concentrator collectors. Intl. J. Therm. Environ. Eng., 5: 13-20.

Sultan, F., F.A. Ali and T.K.A. Razaq, 2012. Tilt angle optimization of solar collectors for maximum radiation in three Iraqi cities. Intl. J. Eng. Ind., 3: 99107.

Winston, R., J.C. Minano and P.G. Benitez, 2005. Nonimaging Optics. Academic Press, Cambridge, Massachusetts, USA., ISBN:9780127597515, Pages: 497. 